\title{
FORMULATION AND ANTIOXIDANT INVESTIGATION OF CREAMS CONTAINING ROBINIAE PSEUDACACIAE FLOS L. ETHANOLIC EXTRACT
}

\author{
TÜNDE JURCA ${ }^{1}$, ANNAMARIA PALLAG ${ }^{1}$, LAURA VICAS $^{1}{ }^{*}$, ELEONORA MARIAN $^{1}$, \\ MARIANA MUREȘAN ${ }^{1}$, ZOLTÁN UJHELYI $^{2,3}$, PÁLMA FEHÉR ${ }^{2,3}$, ILDIKÓ BÁCSKAY ${ }^{2,3,4}$ \\ ${ }^{1}$ University of Oradea, Medicine and Pharmacy Faculty, Department of Pharmacy, 29 Nicolae Jiga Street, 410028, Oradea, \\ Romania \\ ${ }^{2}$ University of Debrecen, Faculty of Pharmacy, Department of Pharmaceutical Technology, Nagyerdei krt 98, 4032 Debrecen, \\ Hungary \\ ${ }^{3}$ Doctoral School of Pharmaceutical Sciences, University of Debrecen, Nagyerdei Körút 98, 4032 Debrecen, Hungary \\ ${ }^{4}$ Institute of Healthcare Industry, University of Debrecen, Nagyerdei Körút 98, 4032 Debrecen, Hungary
}

*corresponding author: laura.vicas@gmail.com

Manuscript received: January 2021

\begin{abstract}
Some vegetable products can be incorporated into skin care products in order to treat conditions such as skin dryness and can function as an antioxidant. Creams were formulated with Robiniae pseudacaciae flos extracts. This study was aimed to investigate the antioxidant activity of the ethanolic extracts and the obtained creams. The fractions of Robiniae pseudacaciae flos were found to be rich sources of polyphenols with marked antioxidant activity, evidenced by the DPPH method. The phenolic acids, identified by HPLC-RP with UV detection, were gallic acid, sinapic acid, caffeic acid and vanillic acid and the predominant flavonoids were quercetin, rutin and luteolin. The extract was previously dissolved in Transcutol and then mixed in the same oil/water $(\mathrm{O} / \mathrm{W})$ base containing Sucrose ester SP50, Tefose ${ }^{\circledR}$ 63, Sedefos ${ }^{\mathrm{TM}} 75$ as emulsifiers. The in vitro release of different compounds was evaluated by the Franz diffusion method. The creams containing Robiniae pseudacaciae flos extract exhibited large amounts of diffused substances. Antioxidant activity was determined by the DPPH (1,1-diphenyl2-pycrylhydrazyl) method, according to the methodology described by Brand-Williams.
\end{abstract}

\section{Rezumat}

Unele produse vegetale pot fi încorporate în produsele de îngrijire ale pielii pentru a trata condiții precum uscăciunea pielii și pot funcționa ca antioxidant. Cremele au fost formulate din extracte de flori de Robinia pseudoacacia L. În acest studiu am urmărit investigarea activităţii antioxidante a extractelor etanolice și a cremelor obținute. Fracțiile extrase din Robiniae pseudacaciae flos au fost surse bogate de polifenoli cu marcată activitate antioxidantă, evidențiată prin metoda DPPH. Acizii fenolici importanți, identificați prin HPLC-RP cu detecție UV, au fost acidul galic, acidul sinapic, acidul cafeic şi acidul vanilic, iar flavonoidele predominante au fost quercetina, rutina şi luteolina. Extractul a fost dizolvat anterior în Transcutol și apoi amestecat în aceeaşi bază cremă ulei în apă (U/A) conținând ester de zaharoză SP50, Tefose ${ }^{\circledR} 63$, Sedefos ${ }^{\mathrm{TM}} 75$ ca emulgatori. Eliberarea in vitro a compușilor a fost evaluată prin metoda difuziei Franz. Cremele ce conțin extract de Robiniae pseudacaciae flos au prezentat mari cantități de substanțe difuzate. Activitatea antioxidantă a fost determinată prin metoda DPPH (1,1-difenil-2-picrilhidrazil), conform metodologiei descrise de Brand-Williams.

Keywords: Robinia pseudoacacia L., antioxidant activity, formulation of creams

\section{Introduction}

Robinia pseudoacacia L. (black locust, false acacia), belonging to the Fabaceae family, originally native from the South-Eastern USA, is widely distributed as wild and cultivated species growing in temperate regions throughout the world [17].

The genus Robinia, commonly known as locust, comprises 10 species of trees and shrubs, characterized by white or pink flowers with intensive, distinctive, sweet aroma [9, 16, 17]. The flowers are white, borne in pendulous racemes of $10-15 \mathrm{~cm}$ long and are edible, with high nutrient and functional values.
The Robiniae pseudacaciae flos are used in the traditional medicine as diuretic, spasmolytic, sedative and cholagogue agents and relieve inflammation of the kidneys and biliary ducts [3, 6, 19].

The investigation for chemical composition of Robinia pseudoacacia $\mathrm{L}$. showed that flowers were rich in proteins and microelements which could be used for additives in foods $[10,12]$. Its' flowers also contain an important bioactive compound called robinin which had an important medicinal usage. The review of the scientific literature indicated that false acacia flowers have been attracting a special interest due to their gentle 
fragrance, given by the containing of an essential oil whose composition depends on geographical region [6]. Flower's volatile compounds have been studied by several researchers, as well as the honey aroma profiles, made from these flowers. The gentle fragrance characteristic of $R$. pseudoacacia flowers is mainly due to the presence of linalool, 1-octen-3-ol and hexahydrofarnesyl acetone in the essential oil [1]. The main bioactive components which are present in false acacia flowers include flavonoids, phenolics, ascorbic acid, etc.). The contents of rutin, epigallocatechin, ferulic acid and quercetin were quantified in studies of Wang et al. [24, 25]. Veitch et al. [22] identified flavonol 3,7di-O-glycosides, flavonoid robinin, glucosyl analogue of robinin, kaempferol, and isorhamnetin in the methanolic extracts obtained by maceration of black locust flowers. Flowers of false acacia contain also volatile compounds, flavonoids, proteins, robinin, polysaccharide and some microelements [8]. The flavonoid content of false acacia represented great interest to researchers.

In 2000, five flavonoids including acacetin, secondiflorol, mucronulatol, isomucronulatol and isovestitol were isolated from the ethanolic extracts of false acacia, following an activity-guided fractionation [5, 20]. Different parts of false acacia have wide application in different areas. Its' flowers could be eaten and are generally used for honey production. The flowers are also used for preparation of cakes. Series of findings support the consumption of edible flowers of the false acacia as functional food and their usage as sources of natural antioxidants in the food industry [26]. Recently, many investigations have been concerned with the antioxidant properties of different nutritional products [15, 21]. Antioxidant ability has usually been attributed to the activity of anti-oxidant enzymes as well as to the content of lowmolecular antioxidants such as carotenoids, tocopherols, ascorbic acid, phenolic substances [2, 3, 24].

The purpose of this study was to evaluate the chemical composition and the antioxidant activity of the Robiniae pseudacaciae flos extract and then to obtain the most suitable formula with potential in the cosmetic applications.

\section{Materials and Methods}

The Robinia pseudacacia L. flowers were collected in June 2017 (Bihor County, Romania). A specimen of the species was kept in the herbarium of the Faculty of Medicine and Pharmacy Oradea, Romania, registered in NYBG Steere Herbarium, UOP code 005067. The collected flowers were kept at $40^{\circ} \mathrm{C}$, for $96 \mathrm{~h}$, and used for preparation of lyophilized dry extracts.

Preparation of the Robinia pseudoacacia L. dry extract for lyophilisation

The Robinia pseudoacacia L. flowers were dried at $40^{\circ} \mathrm{C}$, for $96 \mathrm{~h}$, and used for the preparation of lyophilized extracts. The extraction was made with $70 \%$ aqueous ethanol $(100 \mathrm{~mL})$ using $10 \mathrm{~g}$ of dried flowers mixed with a magnetic mixer for 45 minutes and sonicated for 5 minutes. The extraction yield was $9.2 \%$. After centrifugation, the alcohol was evaporated and the lyophilized extract was then obtained. We followed the methods for preparation of neutral and acidic extracts, published by other studies $[11,15]$. Preparation of neutral the extract

Over fifty mg of dry extract was added to a mixture that consists of $90 \%$ methanol and $0.5 \%$ acetic acid ( $2 \mathrm{~mL}) .2 \mathrm{~mL}$ of naringenin $10 \mathrm{mM}$ were used as internal standard and the sample was centrifuged. The supernatant was evaporated using a rotary evaporator. The residue was dissolved in $1 \mathrm{~mL}$ dimethyl sulfoxide (DMSO) and transferred to a test tube.

\section{Preparation of the acidic extract}

Fifty mg of lyophilized extract was weight and dissolved in $4 \mathrm{~mL} 25 \%$ methanol and then combined with $2 \mathrm{~mL}$ of naringenin $10 \mathrm{mM}$ and $1 \mathrm{~mL}$ of $\mathrm{HCl}(6 \mathrm{M})$ in order to obtain the acidic extract. Then, each sample was mixed in a water bath at $85-90^{\circ} \mathrm{C}$ for 2 hours and afterwards $2.5 \mathrm{~mL}$ of ethyl acetate was added. $1 \mathrm{~mL}$ of DMSO was used to dissolve the residue. After that, we transferred it to a test tube. Unhydrolysed (neutral) and hydrolysed (acidic) extracts were prepared because some phenolic compounds are attached to carbohydrates so it can accentuate them only in acidic medium. In order to characterize the lyophilized extract in terms of physico-chemical properties, we used the RP-HPLC method with UV detection. Therefore, the bioactive compounds found in the Robinia pseudoacacia L. flowers, responsible for the therapeutic effects, were highlighted.

\section{Reagents}

The reagents needed for this study were purchased from Chimopar (Bucharest, Romania) - ethanol; Scharlau ME 0310 (USA) - methanol; Molar Chemicals Kft. (Hungary) - acetic acid, ethyl acetate and dimethyl sulfoxide; J.T. Baker (USA) reagent grade hydrochloric acid; acetonitrile-gradient grade for HPLC was purchased from Sigma Aldrich, USA. All chemicals and reagents were of analytical grade.

For the HPLC method, as standards naringenin, rutin, catechin caffeic, vanillic, gallic, ferulic, sinapic acid were purchased from Sigma-Aldrich, USA. Sodium carbonate and standards: quercetin, epicatechin, luteolin and p-coumarinic acid were provided by Fluka, Switzerland. The reagents used to determine the total polyphenols content (TPC) and to evaluate the antioxidant capacity were 6-hydroxy-2,5,7,8-tetramethylchromane-2-carboxylic acid (Trolox), Folin-Ciocâlteu's reagent, 1,1-diphenyl-2-pycrylhydrazyl (DPPH), 2,4,6Tri(2-pyridyl)-s-triazine (FRAP), naringenin (> 95\%), were purchased from Sigma Aldrich, USA.

In this study, the quantitative analyse of the phenolic compounds was performed by RP-HPLC method, using a system consisted of a LC-10ADVP pump equipped 
with SPD-10AVP Diode Array (UV) detector. Were used a Kinetex 5u RPC $18 \mu \mathrm{g}$ column and a mobile phase made of $0.05 \%$ formic acid and $0.05 \%$ formic acid acetonitrile $(50: 50 \mathrm{v} / \mathrm{v})$.

\section{RP-HPLC analysis}

RP-HPLC was used to determine the compositions of flavonoids and phenolic acids, in neutral and acidic extracts, as previously published by Jurca et al. [7]. From the obtained data, this method was found to be accurate and efficient. As phenolic standards, we used 7 phenolic acids (gallic, caffeic, syringic, sinapic, vanillic, p-coumaric, ferulic) and 7 flavonoids (catechin hydrate, rutine trihydrate, naringenin, luteolin, quercetine dihydrate, epicatechin, myricetin). The standards were dissolved in a mobile phase in order to obtain a 1 $\mathrm{mg} / \mathrm{mL}$ concentration and mixed through a $0.45 \mu \mathrm{m}$ membrane filter and injected to the HPLC system. Analyses were performed in triplicate to have a reproductible response. The quantification of flavonoids was done using a Shimadzu SCL-POA HPLC system with LC-10ADVP pump equipped with SPD-10AVP Photo Diode Array (UV) detector. The column type used was Kinetex 5u RP C18 $2.6 \mu \mathrm{m}$ and preliminary separations of the flavonoids were accomplished using the mobile phase that consists of (A) $0.05 \%$ formic acid and (B) $0.05 \%$ acetonitrile $(50: 50 \mathrm{v} / \mathrm{v})$. The qualitative analysis was performed using the retention times of standards, UV spectra and calculation of the absorbance ratios after co-injection of samples and standards.

For evaluating the antioxidant properties of Robinia pseudoacacia L., we used CUPRAC assay, DPPH and FRAP methods, and for the TPC it was used FolinCiocâlteu reagent.

Evaluation of antioxidant capacity

DPPH method. The DPPH method was used to test the ability of compounds to act as free radical scavengers or hydrogen donors, and to evaluate antioxidant capacity using a slightly modified method [23]. The colour change (from dark violet to light yellow) correlated with the antioxidant capacity was performed on a Shimadzu UV-VIS spectrophotometer at $517 \mathrm{~nm}$. The DPPH methanolic solution $\left(6 \cdot 10^{-5} \mathrm{M}\right)$ was freshly prepared daily before measurements. The samples were kept in the dark for $15 \mathrm{~min}$ at room temperature and then the absorbance was read. To obtain reproductible results, the experiment was carried out in triplicate. Using the following formula:

$$
\% \text { inhibition }=[(\mathrm{AB}-\mathrm{AA}) / \mathrm{AB}] \times 100,
$$

where: $\mathrm{AB}=$ absorption of blank sample $(\mathrm{t}=0 \mathrm{~min})$, $\mathrm{AA}=$ absorption of test extract solution (after $15 \mathrm{~min}$ ), it was determined the free DPPH radical inhibition percentage.

Ferric reducing antioxidant power (FRAP) method. FRAP method evaluates the antioxidant capacity of natural extract and is based on the change in colour from light yellowish-green to blue of the ferric tri- pyridyltriazine complex (FeIII PTZ) and on the reduction of the ferric ion to the ferrous iron (FeII) by a reductant, at an acid $\mathrm{pH}$. To $50 \mathrm{~mL}$ acetate buffer it were added $5 \mathrm{~mL} \mathrm{FeCl}_{3} \cdot 6 \mathrm{H}_{2} \mathrm{O}$ solution and $5 \mathrm{~mL}$ TPTZ solution and Trolox were used as a standard solution. The calibration curve was made for concentrations between 0 and $300 \mu \mathrm{M}$, having a correlation coefficient $\mathrm{R}^{2}=0.9956$ and the regression equation $(\mathrm{y}=0.0017 \mathrm{x}+$ 0.0848 , where y represents absorbance performed at $595 \mathrm{~nm})$. The antioxidant capacity was expressed as $\mu \mathrm{mol}$ Trolox equivalents (TE)/100 g dry weight (DW). Cupric ions $\left(\mathrm{Cu}^{2+}\right)$ reducing - CUPRAC assay. Cuprac method was used to determine the antioxidant activity of the extract. This method was evaluated by using the cupric ions $\left(\mathrm{Cu}^{2+}\right)$ reducing capacity based on the change in colour from light green to reddish-orange of a complex with copper of the neocupreine, 2,9dimethyl-1,10-phenantroline. The CUPRAC reagent was prepared using $0.25 \mathrm{~mL} \mathrm{CuCl}_{2}$ solution $(0.01 \mathrm{M})$, $0.25 \mathrm{~mL}$ ethanolic neocupreine solution $\left(7.5 \times 10^{-3} \mathrm{M}\right)$ and $0.25 \mathrm{~mL}$ ammonium - acetate buffer solution $(1 \mathrm{M})$. Then it was mixed with the plant extracts and the total volume was adjusted to $2 \mathrm{~mL}$ with distilled water. The spectrophotometric determination was performed at $450 \mathrm{~nm}$, after $30 \mathrm{~min}$, and Trolox was used as a standard solution. Increased absorbance of the reaction mixture indicates high reduction capability. The calibration curve was made for concentrations between 0 and $500 \mu \mathrm{M}$ having a correlation coefficient $\mathrm{R}^{2}=0.9935$ and the regression equation $(y=0.0006 x$, where $y$ represents absorbance performed) and the results were expressed as $\mu \mathrm{mol} \mathrm{TE} / \mathrm{g}$ DW.

Phenolic determination (Folin-Ciocâlteu method). The estimation of total phenolic content was determined according to the Folin-Ciocâlteu method [11, 24]. Briefly, the sample $(100 \mu \mathrm{L})$ was mixed with 1750 $\mu \mathrm{L}$ distilled water, $200 \mu \mathrm{L}$ Folin-Ciocâlteu reagent (dilution $1: 10, v / v$ ) and $1000 \mu \mathrm{L}$ of $15 \% \mathrm{Na}_{2} \mathrm{CO}_{3}$ solution, and the mixture was let to stand at room temperature, in the dark, for 2 hours. The TPC was determined at $765 \mathrm{~nm}$ spectroscopically and expressed as $\mathrm{mg}$ gallic acid equivalents (mg GAE)/mL extract. The calibration curve was linear for the range of 0.1 $0.5 \mathrm{mg} / \mathrm{mL}$ gallic acid standard concentrations. Total phenolics were calculated as GAE using the regression equation based on the calibration curve: $\mathrm{y}=1.9735 \mathrm{x}+$ $0.0261\left(R^{2}=0.9928\right)$, where $x$ was the absorbance and y was the $\mathrm{mg} \mathrm{GAE} / \mathrm{mL}$ extract.

Determination of total flavonoids. The total flavonoids content expressed as mg quercetin equivalent QE/ $100 \mathrm{~g}$ was determined using a colorimetric method [7]. From each extract, $1 \mathrm{~mL}$ (containing $0.1 \mathrm{mg} / \mathrm{mL}$ dry matter) was provided and mixed with $4 \mathrm{~mL}$ distilled water and introduced in a $10 \mathrm{~mL}$ volumetric flask; first, $3 \mathrm{~mL} 5 \% \mathrm{NaNO}_{2}$ were added, after 5 minutes $0.3 \mathrm{~mL} 10 \% \mathrm{AlCl}_{3}$ and after 6 minutes $2 \mathrm{~mL} 1 \mathrm{M}$ $\mathrm{NaOH}$. The volumetric flask was filled with distilled water up to its mark. The samples were read using 
water as blank at $510 \mathrm{~nm}$. The equation based on the calibration curve was $\mathrm{y}=56.818571 \mathrm{x}-0.066498$ $\left(R^{2}=0.9983\right)$, where $x$ represents the absorbance and y was the mg quercetin.

Formulation of topical creams containing Robinia pseudacacia L. flowers extract

3 samples of $\mathrm{O} / \mathrm{W}$ cream with different compositions were prepared with ingredients the minimum amount of fatty base [14, 18]. The creams were produced by melting $\left(60^{\circ} \mathrm{C}\right)$ cetostearyl alcohol with stearic acid and isopropyl myristate and mixed in order to prepare the oil phase (Table I). The aqueous phase containing propylene-glycol, emulsifying agent (Sucrose ester SP70, Tefose ${ }^{\circledR} 63$ - mixture of PEG6 stearate and ethylene glycol palmito-stearate and PEG-32 stearate or Sedefos ${ }^{\mathrm{TM}} 75$ - Mixture triceteareth-4 phosphate, ethylene and diethylene glycol stearate), and purified water was heated up to the same temperature $\left(60^{\circ} \mathrm{C}\right)$ and mixed with the oil phase, homogenized and cooled to $25^{\circ} \mathrm{C}$. Then, Nipagin $\mathrm{M}$ (Methyl p-hydroxy-benzoate $\mathrm{M}$ ) was mixed in the preparation and finally, the $10 \%$ Robiniae pseudacaciae flos extract.

Table I

Formulation of creams

\begin{tabular}{|l|c|c|c|}
\hline \multicolumn{1}{|c|}{ Ingredients } & $\begin{array}{c}\text { I (SP70) } \\
\mathbf{g}\end{array}$ & $\begin{array}{c}\text { II (Tefose 63) } \\
\mathbf{g}\end{array}$ & $\begin{array}{c}\text { III (Sedefos 75) } \\
\mathbf{g}\end{array}$ \\
\hline Robinia pseudoacacia L.extract 10\% & 10.00 & 10.00 & 10.00 \\
\hline Transcutol & 1.40 & 1.40 & 1.40 \\
\hline Sucrose ester SP70 & 3.00 & - & - \\
\hline Tefose $^{\circledR}$ 63 & - & 3.00 & - \\
\hline Sedefos $^{\text {TM } 75}$ & - & - & 3.00 \\
\hline Cetostearyl alcohol $^{\text {Stearic acid }}$ & 4.60 & 4.60 & 4.60 \\
\hline Isopropyl myristate & 10.00 & 10.00 & 10.00 \\
\hline Propylene glycol & 5.00 & 5.00 & 5.00 \\
\hline Methyl p-hydroxy-benzoate & 5.00 & 5.00 & 5.00 \\
\hline Distilled water & 1.00 & 1.00 & 1.00 \\
\hline
\end{tabular}

I - sample O/W cream with Sucrose ester SP70; II - sample O/W cream with Tefose ${ }^{\circledR} 63$; III - sample O/W cream with Sedefos ${ }^{\text {TM }} 75$

\section{Consistency examinations of creams}

The resistance of cream formulations was measured using the CT3 Texture analyser (Brookfield, Middleboro, USA). Diffusion test served as a standard method. The following parameters were fixed: trigger load (4 g), target $(10 \mathrm{~mm})$, speed $(0.50 \mathrm{~mm} / \mathrm{s})$. TA5 Cylinder type probe (12.7 $\mathrm{mm}$ diameter and $35 \mathrm{~mm}$ length) was used during the test [13].

In vitro tests with Franz diffusion cell

The membrane diffusion and permeability studies were performed with a vertical Franz-diffusion cell system (Hanson Microette TM Topical and Transdermal Diffusion Cell System). $0.3 \mathrm{~g}$ of sample was placed as donor phase on a cellulose-acetate membrane (pore size $0.45 \mu \mathrm{m}$ ). The pre-treatment of the membrane by soaking in IPM was done. Effective diffusion surface area was $1.767 \mathrm{~cm}^{2} .30 \%(\mathrm{v} / \mathrm{v})$ alcohol was used as an acceptor phase in order to enhance the solubility of extract. Rotation of the magnetic stirrer was set to $450 \mathrm{rpm}$. The receptor medium was thermostated at $32 \pm 0.5^{\circ} \mathrm{C}$ throughout the experiment to imitate the temperature of physiological skin on the membrane in the Franz cell. Experiments were performed for 3 hours. Samples of $0.8 \mathrm{~mL}$ were taken from the acceptor phase and replaced with fresh receiving medium. Quantitative measurement of Robinia pseudoacacia L. extract was carried out with an UV-spectrophotometer (Shimadzu Spectrophotometer, Japan, Tokyo) at a wavelength of $360 \mathrm{~nm}$. Calibration curve was determined before the spectroscopic measurements of black locust. Linear connection was found between the concentration of Robinia pseudoacacia L. extract and the measured absorbance. All experiments were performed in five replicates.

\section{Statistical Analysis}

The data was subjected to statistical analysis two-way ANOVA, followed by Dunnett's multiple test using GraphPad Prism version 4.00 for Windows (GraphPad Software, SD, California, USA, www.graphpad.com). The criterion for statistical significance was $\mathrm{p}<0.05$.

\section{Results and Discussion}

\section{RP-HPLC analysis}

In order to identify and quantify the active principles, mainly the phenolic acid groups, flavonoid glycosides and aglycones from the neutral and acidic extract of Robinia pseudoacacia L., the HPLC-RP with UV detection was used. Chromatograms of the Robinia pseudoacacia L. flowers extracts were recorded at 270, 310 and $360 \mathrm{~nm}$. Throughout this study, we accomplished a more detailed analysis of the polyphenols, using a series of standard compounds, by investigation of the neutral and acidic extracts. The chosen method allows a simultaneous analysis of different classes of polyphenols on one single passing through a column, in a short time interval. Each sample was analysed before (using neutral extract) and after the acid hydrolysis in order to obtain more exact data 
FARMACIA, 2021, Vol. 69, 4

regarding flavonoids and aglycones and to estimate the nature of the respective compounds. The phenolic acids and flavonoid compounds, identified in the analysed samples, are presented in Table II.

Table II

Concentration of flavonoids and phenolic acids components in the Robinia pseudoacacia L. flowers sample were expressed as $\mathrm{mg} / \mathrm{kg} \mathrm{DW}$

\begin{tabular}{|l|c|c|c|}
\hline Bioactive compounds & $\lambda_{\max }$ & Neutral extract $\mathbf{( m g} / \mathbf{k g}$ DW) & Acidic extract (mg/kg DW) \\
\hline Rutin & 275,360 & $875.21 \pm 2.15$ & $159.22 \pm 1.15$ \\
\hline Myricetin & 275,360 & $34.89 \pm 3.02$ & $44.76 \pm 2.01$ \\
\hline Quercetin & 275,360 & 0 & $45.89 \pm 3.33$ \\
\hline Naringenin & 275 & $41.12 \pm 4.03$ & $95.62 \pm 3.45$ \\
\hline Catechin & 275 & $409.74 \pm 1.07$ & $231.45 \pm 2.67$ \\
\hline Apigenin & 275,360 & $12.23 \pm 1.78$ & $7.84 \pm 3.12$ \\
\hline Luteolin & 360 & 0 & $34908.41 \pm 2.65$ \\
\hline p- Coumaric acid & 310 & $81.54 \pm 5.03$ & $12.34 \pm 2.08$ \\
\hline Gallic acid & 275 & $234.51 \pm 1.43$ & $20.31 \pm 1.35$ \\
\hline Ferulic acid & 310 & 0 & 0 \\
\hline Syringic acid & 275 & $15.51 \pm 5.23$ & $42.13 \pm 2.37$ \\
\hline Sinapic acid & 310 & $63.24 \pm 2.75$ & $114.34 \pm 3.85$ \\
\hline Caffeic acid & 310 & $15.51 \pm 3.83$ & $86.34 \pm 5.12$ \\
\hline Vanillic acid & 275 & $81.25 \pm 1.93$ & $236.32 \pm 2.91$ \\
\hline
\end{tabular}

Five glycosides (naringenin, apigenin, catechin, rutin and myricetin) were highlighted in the neutral extract and six phenolic derivates: sinapic acid, p-coumaric acid, caffeic acid, gallic acid, vanillic acid and syringic acid. The dominant compound, amoung the phenolic acids, was the gallic acid $(234.51 \pm 1.43 \mu \mathrm{g} / \mathrm{g}$ DW). Regarding the flavonoids, the predominant compound in the extract's composition, is rutin $(875.21 \pm 2.15)$ and catechin $(409.74 \pm 1.07 \mu \mathrm{g} / \mathrm{g} \mathrm{DW})$. The presence of sinapic acid, syringic acid, luteolin, naringenin and quercetin in the acidic extract was suggestive, being released from their corresponding glycosylated structures. The main compound in acidic extract was luteolin and vanillic acid. These phenolic compounds provide antioxidant activity by direct reducing of reactive oxygen species, inhibiting enzymes involved in oxidative stress, binding metal ions responsible for the production of reactive oxygen species and stimulating the endogenous antioxidant defence systems. Compared with other reports, we observed that flowers contain the highest number of flavonoids in the range $0.15-0.9 \mathrm{mg} / \mathrm{mL}[10]$. In the research conducted by Călina et al. [4], the focus was set to determine two flavonoids, such as rutin and hyperoside in the methanolic extracts from flowers, leaves, bark and seeds. The flower extract contained more hyperoside $(0.9 \mathrm{mg} / \mathrm{mL})$ than the leaf extract $(0.17 \mathrm{mg} / \mathrm{mL})$ and in the case of rutin, the leaves contained almost six times more rutin than the flowers $(0.98 \mathrm{mg} / \mathrm{mL} v s$. $0.17 \mathrm{mg} / \mathrm{mL}$ ). Other studies identified in the ethanolic leaves extract, catechin $(0.925 \mu \mathrm{g} / \mathrm{mL})$, rutin $(0.831$ $\mu \mathrm{g} / \mathrm{mL})$, resveratrol $(0.664 \mu \mathrm{g} / \mathrm{mL})$ and quercetin $(0.456$ $\mu \mathrm{g} / \mathrm{mL})$, whereas in the seed extract the amount of catechin, epicatechin and rutin was observed in high amounts $(0.127 \mu \mathrm{g} / \mathrm{mL}, 0.239 \mu \mathrm{g} / \mathrm{mL}$ and respectively $0.231 \mu \mathrm{g} / \mathrm{mL}$ ) [9].

Evaluation of antioxidant capacity

To evaluate the antioxidant capacity, we determined the total polyphenol content and the flavonoids amount in the alcoholic extract by using the Folin-Ciocâlteu method. The TPC of the alcoholic plant extract was expressed in milligram equivalents of gallic acid per gram of dry weight (mg GAE/g DW), and the total amount of flavonoids in milligram equivalents of quercetin per gram of dry weight (mg QE/g DW); the results are summarized in Table III. The FolinCiocâlteu method generally used to assay the TPC, also measures the total reducing capacity of a sample. The total phenols generally correlate with the redox status and the antioxidant capacities as measured by the DPPH methods. The antioxidant capacity of samples, measured by different complementary assays, is shown in Table IV. The antioxidant properties of Robinia pseudoaccacia L. flowers were tested by measuring their ability to scavenge DPPH and by using CUPRAC and the FRAP methods.

All analyses were mean of triplicate measurements \pm SD. Means not sharing a common letter were significantly different at $\mathrm{p}<0.05$.

Table III

The total polyphenols and flavonoids content

\begin{tabular}{|l|c|}
\hline \multicolumn{1}{|c|}{ Total bioactive compounds } & Lyophilized extract of Robinia pseudacacia L. flower \\
\hline Content of total polyphenols (TPC) (mg GAE/g DW) & $311.925 \pm 0.010$ \\
\hline Total flavonoids (mg QE/g DW) & $0.427 \pm 0.010$ \\
\hline
\end{tabular}

*Data is expressed as mean \pm standard deviation. Different letters in the same column indicate significant differences. The results are generated within the one-way ANOVA and Tukey's Multiple Comparison Test $(\mathrm{p}<0.05)$. 
Regarding the polyphenolic and flavonoids content, there were reported $0.77 \mathrm{mg}$ GAE$/ \mathrm{mL}$, respectively $0.17 \mathrm{mg} \mathrm{QE} / \mathrm{mL}$. The higher values of copper and nickel found in acacia flowers are correlated to the antioxidant activity. Recently, Marinas et al. [11], reported that the highest content of polyphenols was found in the leaf extract $(266.7 \mu \mathrm{g} \mathrm{GAE} / \mathrm{mL}$ extract), respectively in the seeds extract $(232.2 \mu \mathrm{g} \mathrm{GAE} / \mathrm{mL}$ extract). The results of this study clearly show the

presence of substantial amounts of phenolic and flavonoid components in the Robina pseudoacacia L. flowers, which can be considered as good sources for medicinal and food application. A strong correlation was observed between the DPPH and Folin-Ciocâlteu assays.

The obtained extract and physico-chemically characterized was used to obtain the topical preparations.

Table IV

Antioxidant capacity of the Robinia pseudacacia L. flower

\begin{tabular}{|c|c|c|c|}
\hline Sample & DPPH\% & Cuprac $(\boldsymbol{\mu m o l ~ T E} / \mathbf{g}$ DW $)$ & FRAP $(\boldsymbol{\mu m o l ~ T E} / \mathbf{g D W})$ \\
\hline Lyophilized extract of Robinia pseudoacacia L. flower & $3.58 \pm 0.11$ & $0.673 \pm 0.980$ & $2.147 \pm 0.040$ \\
\hline
\end{tabular}

*Data is expressed as mean \pm standard deviation. Different letters in the same column indicate significant differences. The results are generated within the one-way ANOVA and Tukey's Multiple Comparison Test $(\mathrm{p}<0.05)$.

\section{Result of the creams consistency examinations}

The compression force $(\mathrm{mN})$ applied to creams is shown in Figure 1. Differences in the compression force between formulations I - III were measured. However, the strength of the cream containing SP70 has higher values compared to the other formulas.

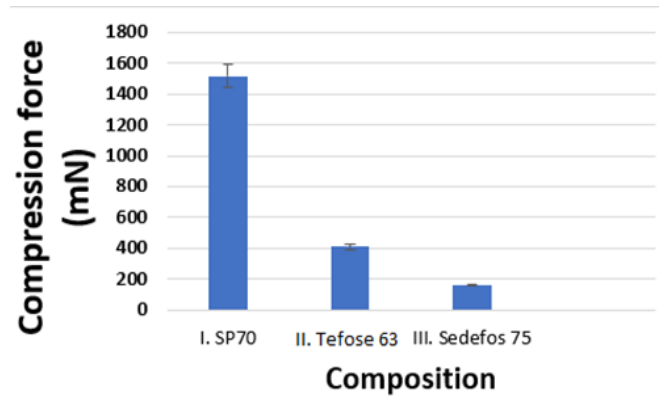

Figure 1.

Consistency of creams

Results of texture analysis

The composition with SP70 as an emulsifying agent presented the highest consistency. The compression force was $1517(\mathrm{mN})$. The compression force was much lower for the other compositions. These creams showed softer consistency. The composition with Tefose ${ }^{\circledR} 63$ presented a compression force $410 \mathrm{mN}$, and the composition with Sedefos ${ }^{\text {TM }} 75$ had only $161.3 \mathrm{mN}$. Higher values of the compressive strength in cream do not correspond to the application on the skin. Formula II (Tefose ${ }^{\circledR} 63$ ) with the compression force at $410 \mathrm{mN}$ is most suitable for skin flaunting. Results of in vitro release studies

The in vitro release study of the bioactive principles in the prepared creams was performed in relation to the emulsifying agents used for their formulation. The test was carried out at the wavelength of $360 \mathrm{~nm}$ as most of the flavonoid components of Robiniae pseudacaciae flos extract (rutin, quercetin, luteolin, myricetin) present a maximum absorption of this wavelength. The diffusion profiles of these bioactive principles through synthetic membranes from different formulations are shown in Figure 2.

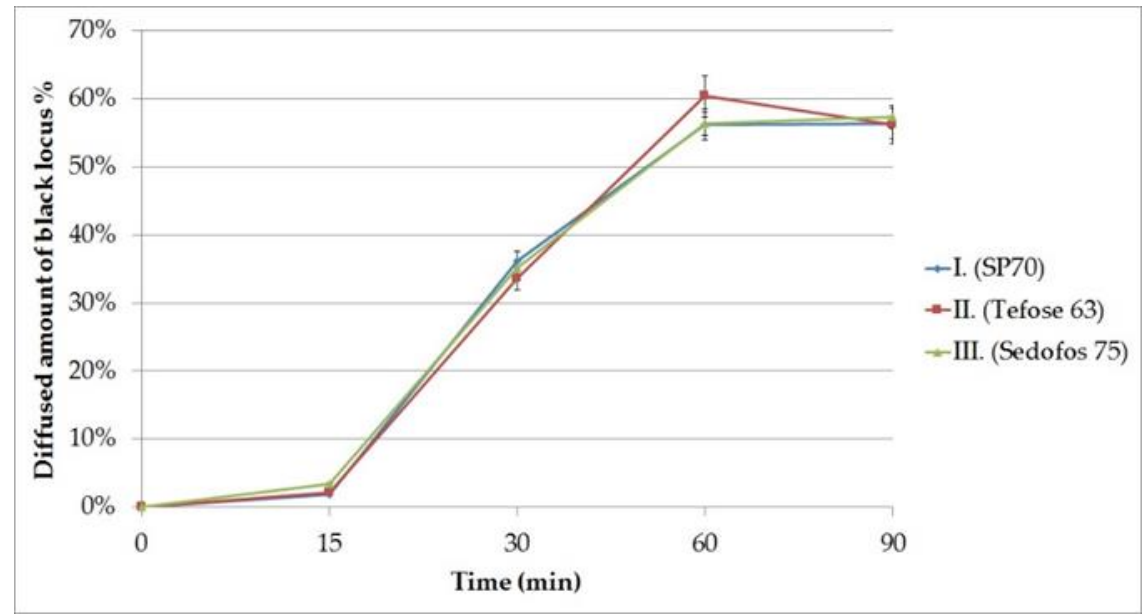

Figure 2.

In vitro examination with Franz diffusion cell 
FARMACIA, 2021, Vol. 69, 4

The release of the bioactive components from different formulations after $60 \mathrm{~min}$ can be sorted based on the following descending order II > I = III. Our results showed that the bioactive compound release was higher from the formulation containing Tefose ${ }^{\circledR} 63$ as an emulgent, the diffused bioactive compound amount was $60 \%$ after $60 \mathrm{~min}$. The formulations with SP70 and Sedefos 75 emulsifying agents showed similar diffusion properties, the diffused amount of the bioactive components was $56 \%$ after $60 \mathrm{~min}$.

\section{Conclusions}

The present study showed that flowers of false acacia (R. pseudoacacia L.) present high levels of phenolic compounds and minerals, with pronounced antioxidant properties. This is a reason for more thorough examination and extensive research of the chemical and biochemical properties of false acacia flowers as a potential raw material for the food, pharmaceutical and cosmetic industries. In our study, topical formulations containing different emulsifiers have been designed and have influenced penetration and bioavailability of bioactive principles. Topical application of creams can exhibit the antioxidant activity in order to reduce cellular stress. Our creams formulas are based on how the surfactants used influence the release of the phytocomplex from Robiniae pseudacaciae flos extract. Following the performed studies, we appreciate that the formula containing Tefose ${ }^{\circledR} 63$ as an emulsifier has a higher yield capacity of bioactive principles. We can conclude that this cream can be used as an effective natural formulation for skin aging.

\section{Acknowledgement}

The present work was supported by grant from The Ministry of Hungary Domus Hungarica 2016.

The research was supported by the Thematic Excellence Programme (TKP2020-IKA-04) of the Ministry for Innovation and Technology in Hungary.

The publication is supported by the GINOP-2.3.415-2020-00008 project. The project is co-financed by the European Union and the European Regional Development Fund.

\section{Conflict of interest}

The authors declare no conflict of interest.

\section{References}

1. Agnieszka K, Monioka Anna O, Maria W, Preliminary study on the composition of volatile fraction of fresh flowers and leaves of Robinia Pseudoacacia L. growing in Poland. Acta Pol Pharm., 2015; 72(6): 1217-1222.

2. AlBasher G, Abdel-Daim MM, Almeer R, Ibrahim KA, Hamza RZ, Bungău S, Aleya L, Synergistic antioxidant effects of resveratrol and curcumin against fipronil-triggered oxidative damage in male albino rats. Environ Sci Pollut Res Int., 2020; 27(6): 6505-6514.
3. Bernatoniene J, Masteikova R, Davalgiene J, Peciura R, Gauryliene R, Bernatoniene R, Majiene D, Lazauskas R, Civinskiene G, Velziene S, Muselik J, Chalupova Z, Topical application of Calendula officinalis (L.): Formulation and evaluation of hydrophilic cream with antioxidant activity. J Med Plants Res., 2007; 5(6): 868-877.

4. Călina D, Olah NK, Pătru E, Docea A, Popescu H, Bubulica MV, Chromatographic analysis of the favonoids from Robinia pseudoacacia species. Curr Health Sci J., 2013; 39(4): 232-236.

5. Fadli AG, Isnaini N, Maryam S, Formulation and Investigation Antioxidant of $\mathrm{O} / \mathrm{W}$ Cream Containing Euphorbia hirta L. Herb Extract. E3S Web Conf., 2020; 151: 1-4.

6. Jing L, Qiu H, Yang L, Liu M, Gao Z, Nutrition in the Pagoda flower. Chin J Spectr Lab., 2002; 19: 36-38, (available in Chinese).

7. Jurca T, Baldea I, Filip AG, Olteanu D, Clichici S, Pallag A, Vicaș L, Marian E, Micle O, Muresan M, The effect of Tropaeolum majus L. on bacterial infections and in vitro efficacy on apoptosis and DNA lesions in hyperosmotic stress. J Physiol Pharmacol., 2018; 69(3): 391-401.

8. Karre L, Lopez K, Getty JK, Natural antioxidants in meat and poultry products. Meat Sci., 2013; 94(2): 220-227.

9. Kicel A, Olszewska MA, Owczarek A, Wolbiś M, Preliminary study on the composition of volatile fraction of fresh fowers and leaves of Robinia pseudoacacia L., growing in Poland. Acta Pol Pharm., 2015; 72(6): 1217-1222.

10. Lacatusu I, Arsenie LV, Badea G, Popa O, Oprea $\mathrm{O}$, Badea N, New cosmetic formulations with broad photoprotective and antioxidative activities designed by amaranth and pumpkin seed oils nanocarriers. Ind Crops Prod., 2018; 123: 424-433.

11. Marinas I, Oprea E, Geana EI, Chifiriuc C, Lazar V, Antimicrobial and antioxidant activity of the vegetative and reproductive organs of Robinia pseudoacacia. J Serb Chem Soc., 2014; 79(11): 1363-1378.

12. Martina CM, Schanzera S, Haaga SF, Casetti F, Müller LM, Wölfle U, Kleemann A, Lademanna J, Schempp $\mathrm{CM}$, In vivo photoprotective and anti-inflammatory effect of hyperforin is associated with high antioxidant activity in vitro and ex vivo. Eur J Pharm Biopharm., 2012; 81(2): 346-350.

13. Moldovan ML, Bogdan C, Iurian S, Roman C, Oniga I, Bendec D, Phenolic content and antioxidant capacity of pomace and canes extracts of some Vitis vinifera varieties cultivated in Romania. Farmacia, 2020; 68(1): 15-21.

14. Namngam $C$, Pinsirodom $P$, Antioxidant properties, selected enzyme inhibition capacities, and a cosmetic cream formulation of Thai mango seed kernel extracts. Trop J Pharm Res., 2017; 16(1): 9-16.

15. Pîrvu L, Sha'at F, Păvăloiu R, Udeanu DI, Albu B, Studies on Acinos alpinus L.: polyphenols and terpenoids compounds profile, antimicrobial activity, antioxidant effect and release experiments on the ethanol and propylene glycol extracts. Farmacia, 2019; 67(6): 1025-1033. 
16. Sârbu I, Stefan N, Oprea A, Vascular plants of Romania. An illustrated field guide, Victor B Victor Ed., 2013; 245-246, (available in Romanian).

17. Stankov S, Fidan H, Ivanova T, Stoyanova A, Damyanova S, Desky M, Chemical composition and application of flowers of false acacia (Robinia pseudoacacia L.). Food Technol., 2018; 7(4): 577-588.

18. Stojiljković D, Tadić V, Stanković M, Roganović S, Arsić I, Standardized extract of wild apple fruit in alkyl-polyglucoside-based cosmetic cream - estimation of stability, safety, antioxidant activity and efficiency. Int J Cosmet Sci., 2018; 40(3): 285-294.

19. Strzelecka H, Kowalski J, The Encyclopedia of Herbs and Herbalism, PWN, Warszawa, 2000

20. Tian F, McLaughlin J, Bioactive flavonoids from the black locust tree, Robinia pseudoacacia. Pharm Biol., 2000; 38(3): 229-334.

21. Toma CC, Olah NK, Vlase L, Mogoșan C, Mocan A, Comparative Studies on Polyphenolic Composition, Antioxidant and Diuretic Effects of Nigella sativa L. (Black Cumin) and Nigella damascena L. (Lady-ina-Mist) Seeds. Molecules, 2015; 20(6): 9560-9574.
22. Veitch NC, Elliott PC, Kite GC, Lewis GP, Flavonoid glycosides of the black locust tree, Robinia pseudoacacia (Leguminosae). Phytochemistry, 2010; 71(4): 479-486.

23. Vlase L, Benedec D, Hanganu D, Damian G, Csillag I, Sevastre B, Mot AC, Silaghi-Dumitrescu R, Tilea I, Evaluation of antioxidant and antimicrobial activities and phenolic profile for Hyssopus officinalis, Ocimum basilicum and Teucrium chamaedrys. Molecules, 2014; 19(5): 5490-5507.

24. Wang X, Tang L, Zhao L, Optimization of ultrasoundassisted extraction of phenolic compounds from $R$. pseudoacacia $\mathrm{L}$. flowers by response surface methodology. Food Science, 2011; 32: 36-40.

25. Wang X, Tang L, Zhao L, Luan Y, Zhang Z, Determination of polyphenols in flowers of $R$. pseudoacacia L. by Folin-Ciocâlteu method. Food Drug, 2010; 12: 332-334, (available in Chinese).

26. Xie J, Sun B, Yu M, Constituents of top fragrance from fresh flowers of Robinia Pseudoacacia L. occurring in China. Flavour Frag J., 2006; 21: 798-800. 